\title{
ADDITIONS TO THE FRESHWATER FAUNA OF HEARD ISLAND
}

\author{
by H. J. G. Dartnall
}

(with two text-figures and one table)

\begin{abstract}
Dartnali, H.J.G., 2003 (19: xii): Additions to the freshwater fauna of Heard Island. Papers and Proceedings of the Royal Society of Tasmania 137: 75-79. https://doi.org/10.26749/rstpp.137.75 ISSN 0080-4703. School of Biological Sciences, Macquarie University, Sydney, New South Wales 2109, Australia.

Freshwater collections from Heard Island yielded a fauna of protozoans, one species of platyhelminth, two species of tardigrades, at least four species of nematodes, 16 species of rotifer (including two new species and four new records for the island), one species of enchytraeid worm, and nine species of arthropod (four anomopodans, two copepods and three mites). No ostracods were found, nor was any evidence of insects with aquatic or semi-aquatic larvae.
\end{abstract}

Key Words: freshwater invertebrates, rotifers, subantarctic, Heard Island.

\section{INTRODUCTION}

Heard Island at $52^{\circ} 58^{\prime}-53^{\circ} 12^{\prime} \mathrm{S} ; 73^{\circ} 15^{\prime}-73^{\circ} 51^{\prime} \mathrm{E}$, in the southern Indian Ocean, is one of the most isolated and probably the least well-known of the subantarctic islands. It has no permanent bases and is only visited sporadically. This paper describes the freshwater invertebrates collected in October/November 2000, and during February 2001. The first collection included material from some of the more isolated parts of the island, whilst the second was confined to areas near Atlas Cove, and to the eastern end of the island round Scholes Lagoon (fig. 1).

\section{SITE DESCRIPTION}

Heard Island is a volcanic island (surface area $385 \mathrm{~km}^{2}$ ) situated south of the Antarctic convergence in the southern Indian Ocean. With more than $65 \%$ of the island covered in glaciers (Doug Thost, pers. comm.), bodies of freshwater are confined to the coastal lowlands. Global warming has led to the retreat of many of the Heard Island glaciers that only a few years ago terminated in the sea. This has resulted in the formation and enlargement of large proglacial lakes contained within the terminal and lateral moraines at the snout of these glaciers. Extensive breaching of the terminal moraine by the sea at Compton Lagoon, intermittent breaching at Winston Lagoon and minor breaching at Stephenson Lagoon has resulted in seawater incursions and loss of lake water. The locations of the major lacustrine features together with those freshwater lakes sampled on this expedition are shown in figure 1.

Manning Lagoon on the south coast is not fed by glaciers (unlike Winston, Stephenson and Brown lagoons) and is confined by a beach barrier and sand dunes. The surrounding vegetation, known as pool complex (Whinam 1989) consists of Poa cookii (J.D. Hook) J.D. Hook, which grows as a $0.3 \mathrm{~m}$ high tussock, and the cushion plant Azorella selago J.D. Hook. At the time of the first collection there was an ice crust on the water and the surrounding pool complex was snow-covered.

The small lake at Cape Gazert is on the outside of the ice-cored lateral moraine on the southern flank of the Vahsel Glacier. A cobble beach separates the lake from the sea, while inland and to the northeast there is an ice-cored moraine. At the time of sampling the lake was ice-covered, with a 4 $\mathrm{m}^{2}$ patch of open water.
The North West Cornice site consisted of a pool $(0.5 \mathrm{~m}$ deep) and a nearby fast-flowing stream just $1.5 \mathrm{~m}$ across and $0.15 \mathrm{~m}$ deep. The area, which is enriched by penguin guano, is rocky with a surrounding Poa cookii water meadow. Patches of green algae were seen on the bottom of the pool.

Red Island Lagoon is on the northern promontory of Laurens Peninsula. The water at the time of sampling was described as 'a pale green soup' and is an Elephant seal wallow.

Wharf Point Lagoon on the eastern shore of Atlas Cove is a coastal lagoon $(30 \mathrm{~m}$ by $10 \mathrm{~m})$ separated from the sea by a beach ridge. As with Manning Lagoon, there is no glacial input into this lake and it is surrounded by Poa cookii and Azorella selago. Numerous Fur seals and Elephant seals were present and they have caused a wallows site (Wharf Point wallows) to be formed adjacent to, and to the east of, this lagoon.

The small lake on the western side of Azorella Peninsula was visited once, when it was still frozen over, and the surrounding vegetation was partially snow covered. A tiny patch of open water allowed the net to be inserted. The same conditions affected the small pond at Saddle Point.

The Dovers Moraine pools are a series of tarns among the moraines that run parallel to the Dovers Moraine. Up to $1.2 \mathrm{~km}$ from the coast, and some $50 \mathrm{~m}$ above sea level, they are small (the largest was some 50 by $25 \mathrm{~m}$ ) and shallow. The surrounding vegetation ranged from barren soils with occasional Pringlea antiscorbutica R.Br. ex J.D. Hook, Colobanthus kerguelensis J.D. Hook, Poa kerguelensis (J.D. Hook) Strudel and Bryum spp. mosses to closed communities of Azorella selago and Acaena magellanica (Lam.) Vahl.

Scholes Lagoon is a very shallow, possibly ephemeral, lagoon at the western end of Spit Point.

Winston Lagoon is a proglacial lake with a glacial beach barrier that is frequently breached by the sea but was intact when sampled. During a botanical survey of the small island in this lagoon, a wet patch was sampled for freshwater invertebrates.

\section{MATERIALS AND METHODS}

Samples were obtained with cone-shaped plankton nets $50 \mathrm{~cm}$ long, $25 \mathrm{~cm}$ in diameter, and covered with a $35 \mu \mathrm{m}$ mesh. The net was cast into the water and slowly retrieved 


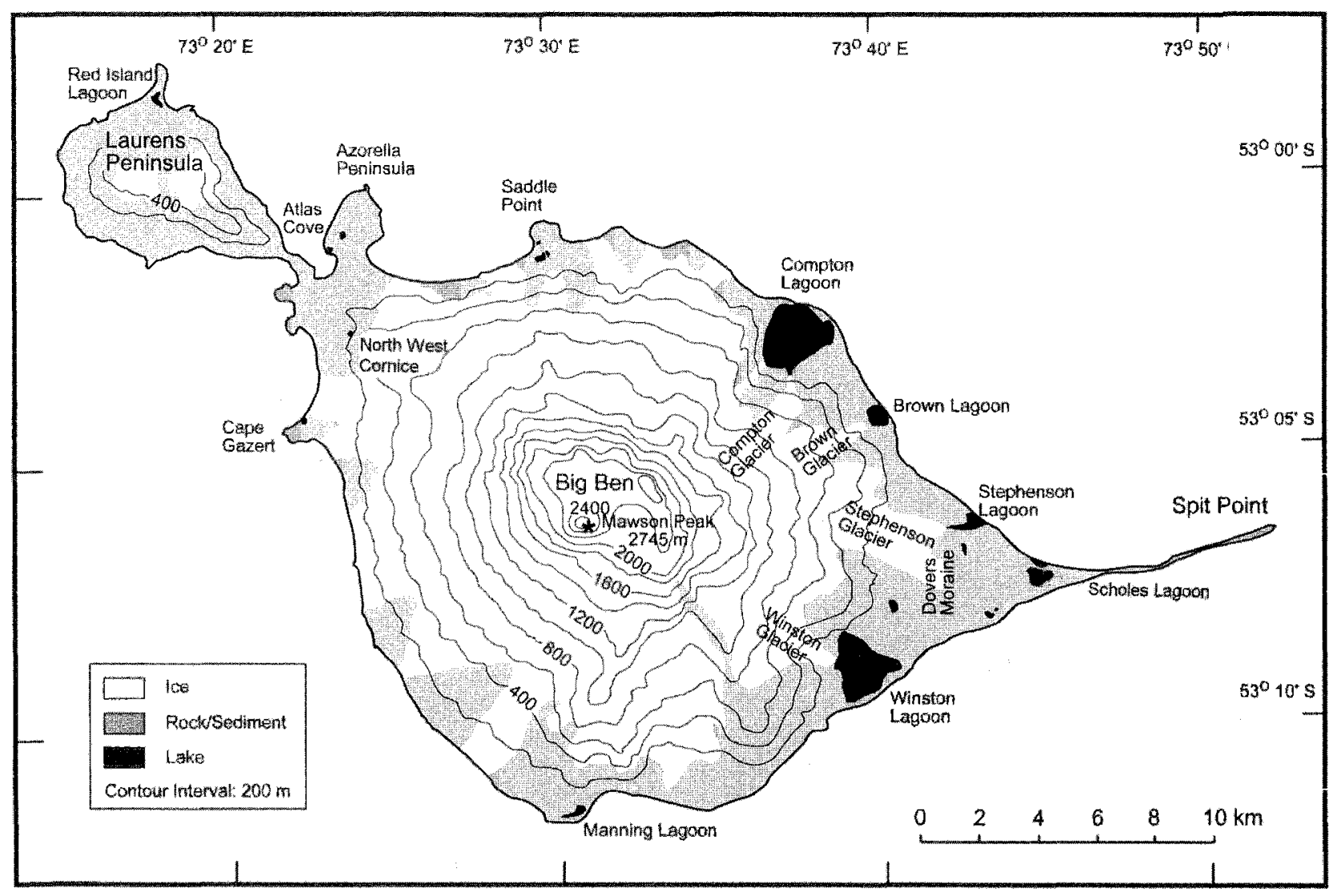

FIG. 1-Map of Heard Island showing the locations of the sampling sites and other major freshwater bodies.

with the net opening on, or just above, the bottom so that it brushed through the benthic vegetation. The samples were stored in cool conditions $\left(<4^{\circ} \mathrm{C}\right)$ until examination in Hobart using a dissecting mictoscope. Drawings were made from free-swimming specimens or from live specimens kept under slight compression by a coverslip mounted on Vaseline. Whole mounts, and slides of trophi were made using polyvinyl-lactophenol (PVL) after Russell's (1961) method.

\section{RESULTS}

The results of the 2000/2001 freshwater collections are given in table 1 . Although the nets were not ideal for collecting Protozoa, small spherical and elongate, brown to colourless ciliates were noted at a number of locations, and a testate amoeba (Arcella sp.) was recovered from the small lake on the Azorella Peninsula. A solitary gastrotrich covered in sensory bristles (Chaetonotus sp.) was recovered from Manning Lagoon. Tardigrades were recovered from a number of sites. They were not identified but Acutuncus (=Hypsibius) antarcticus and Dactylobiotus sp. were recorded in an earlier survey (Dartnall 1995). Four species of nematode were regularly encountered. They were differentiated only by size, and probably represent more than four species. An additional nematode (5th sort) was recovered from wet ground on the island in Winston Lagoon but this is probably a terrestrial species.
Rotifers were represented by 16 species (11 Monogononta and five Bdelloidea). Of these, nine-Encentrum heardensis, E. mustela, Epiphanes senta, Lepadella patella, L. triptera, Notholca hollowdayi, Trichocerca brachyura, Adineta sp. and Rotaria rotatoria - have previously been reported from Heard Island (Dartnall 1995); four - Cephalodella gibba, Encentrum uncinatum, Adinata vaga and Habrotrocha constricta - are common species with a worldwide distribution including the subantarctic (Paggi S. 1982, Dartnall \& Hollowday 1985, Dartnall, 1993, De Smet 2001). Two records - a Notholca and a Dicranophorus - are new species.

\section{Notholca sp. \\ Fig. 2A, B}

Two specimens of this species were found in the small tarns at the eastern end of the island (Dovers Moraine pools). They have the characteristic ' $U$ '-shaped lorica adorned with six anterior spines typical of the genus Notholca. The anterior spines are needle-like and in one specimen the centre pair has a distinct bias (fig. 2B). The lorica is smooth or slightly striated, which is characteristic of the 'labis' group. The posterior region of the dorsal lorica is extended some 70 $\mu \mathrm{m}$ in a spatulate fashion. Longitudinal indentations in this extension give the illusion of a foot segment with two short toes. At $285 \mu \mathrm{m}$ this species is considerably bigger than $N$. hollowdayi, the commonest rotifer on Heard Island. 
TABLE 1

The distribution of freshwater invertebrates found at Heard Island during the summer of 2000-01

\begin{tabular}{|c|c|c|c|c|c|c|c|c|c|c|c|c|c|c|}
\hline & 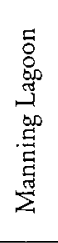 & 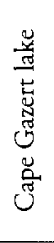 & 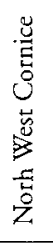 & E & 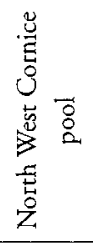 & 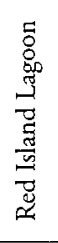 & 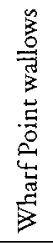 & 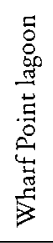 & 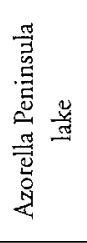 & 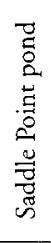 & 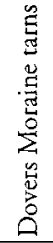 & $\begin{array}{l}5 \\
0 \\
80 \\
3 \\
3 \\
0 \\
0 \\
0 \\
\frac{0}{0} \\
0\end{array}$ & 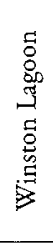 & also known from \\
\hline \multicolumn{15}{|l|}{ Protozoa } \\
\hline ciliates & + & & + & + & & + & + & & & & + & + & & \\
\hline Arcella sp. & & & & & & & & & + & & & & & \\
\hline \multicolumn{15}{|l|}{ Plathyhelminthes } \\
\hline Platyhelminth & + & & & & & & + & & & & + & & & \\
\hline \multicolumn{15}{|l|}{ Gastrotricha } \\
\hline Chaetonotus sp. & + & & & & & & & & & & & & & \\
\hline \multicolumn{15}{|l|}{ Tardigrada } \\
\hline \multicolumn{14}{|l|}{ Dactylobiotus sp. } & SO, SS \\
\hline \multicolumn{15}{|l|}{ Nematoda } \\
\hline Large nematode* & + & & + & + & + & & + & & & & + & & & \\
\hline Medium nematode* & & & + & + & + & & + & + & & & + & & & \\
\hline Monhystera sp. & + & & & & + & & + & + & & & + & + & + & \\
\hline Tiny whip nematode* & + & & & & & & + & + & & & + & & & \\
\hline 5th sort ${ }^{*}$ & & & & & & & & & & & & & + & \\
\hline \multicolumn{15}{|l|}{ Rotifera: Monogononta } \\
\hline Cephalodella gibba (Ehrenberg)* & + & & + & + & & & & + & & & + & & & $\mathrm{Mq}, \mathrm{K}, \mathrm{SG}, \mathrm{SO}, \mathrm{SS}$ \\
\hline Dicranophorus new species* & + & & & & & & & & & & & & & New Species \\
\hline Encentrum heardensis Dartnall & & & & & & & + & + & & & + & & & \\
\hline Encentrum mustela (Milne) & + & & & & & & & + & & & & & & $\mathrm{SG}, \mathrm{SO}, \mathrm{SS}$ \\
\hline Encentrum uncinatum (Milne)* & & & & & & & & + & & & & & & $\mathrm{K}, \mathrm{SO}$ \\
\hline Epiphanes senta O F Müller & & & & & & & + & & & & + & & & $\mathrm{Mq}, \mathrm{SG}, \mathrm{SO}, \mathrm{SS}$ \\
\hline Lepadella patella (O F Müller) & & & & & & & & & & & + & & & $\mathrm{Mq}, \mathrm{K}, \mathrm{SG}, \mathrm{SS}$ \\
\hline Lepadella triptera Ehrenberg & & & & & & & & & & & + & & & $\mathrm{Mq}, \mathrm{SO}, \mathrm{SS}$ \\
\hline Notholca hollowdayi Dartnall & + & + & + & + & + & + & + & + & + & + & & & & $\mathrm{K}$ \\
\hline Notholca new species* & & & & & & & & & & & + & & & New species \\
\hline Trichocerca brachura (Gosse) & & & & & & & & & & & & + & & $\mathrm{Mq}, \mathrm{SG}, \mathrm{SO}$ \\
\hline \multicolumn{15}{|l|}{ Rotifera: Bdelloidea } \\
\hline Adineta vaga Davis* & & & & & & & & & & & + & & & $\mathrm{Mq}$ \\
\hline Adineta sp. & + & + & & & & & + & + & + & & & & & $\mathrm{Mq}, \mathrm{SG}, \mathrm{SO}, \mathrm{SS}$ \\
\hline Habrotrocha constricta Dujardin ${ }^{*}$ & & & & & & & & & & & & & & $\mathrm{SG}, \mathrm{SO}$ \\
\hline live bearing bdelloid $3 / 3$ & + & + & & & & + & & + & + & & & & + & \\
\hline unidentified bdelloid & & & + & + & + & & & & & & + & + & & \\
\hline \multicolumn{15}{|l|}{ Annelida: Oligochaetae } \\
\hline Allolobophora tenuis Eisen & + & + & + & + & & & + & & & & & & & $\mathrm{Mq}, \mathrm{K}$ \\
\hline \multicolumn{15}{|l|}{ Arthropoda: Anomopoda } \\
\hline Alona weinecki Studer & + & & & & + & & & & + & & & + & & $\mathrm{Mq}, \mathrm{K}, \mathrm{SG}, \mathrm{SO}, \mathrm{SS}$ \\
\hline Pleuroxus wittsteini Studer & + & & & & + & + & & & & & & & & $\mathrm{K}$ \\
\hline Macrothrix hursuiticornis Norman \& Brady & + & & & & + & & & & & & + & & & $\mathrm{Mq}, \mathrm{K}, \mathrm{SG}, \mathrm{SO}$ \\
\hline Daphniopsis studeri Ruhe & + & & + & + & & & & + & & & + & + & + & $\mathrm{K}$ \\
\hline \multicolumn{15}{|l|}{ Arthropoda: Copepoda } \\
\hline Boeckella brevicaudata (Brady) & + & + & + & + & & & & + & + & + & + & + & + & $\mathrm{Mq}, \mathrm{K}$ \\
\hline Epactophanes richardi antarcticus (Richters) & + & & & & & + & + & & & & + & & & $\mathrm{K}$ \\
\hline \multicolumn{15}{|l|}{ Arthropoda: Acarina } \\
\hline mites & + & & + & + & + & + & + & & + & + & + & & & \\
\hline \multicolumn{15}{|l|}{ Others } \\
\hline dead springtail & & & & & & + & & & & & & & & \\
\hline dead marine copepod & & + & & & & & & & & & & & & \\
\hline remains larval diptera & + & & & & & & & & & & & & & \\
\hline
\end{tabular}

$+=$ present $^{*}=$ new record for Heard Island; Mq = Macquarie Island: Evans 1970, Frey 1988, Dartnall 1993; K = Kerguelen: Lair \& Koste 1984, Duchene 1989, De Smet 2001; SG = South Georgia: Dartnall \& Heywood 1980, Dartnall unpublished; SO = South Orkney Is.: Heywood et al 1979, 1980; Dartnall \& Hollowday, 1985; SS = South Shetland Is.: Paggi S. 1982, Kuczynski 1987, Paggi J. 1987, Janiec 1993. 


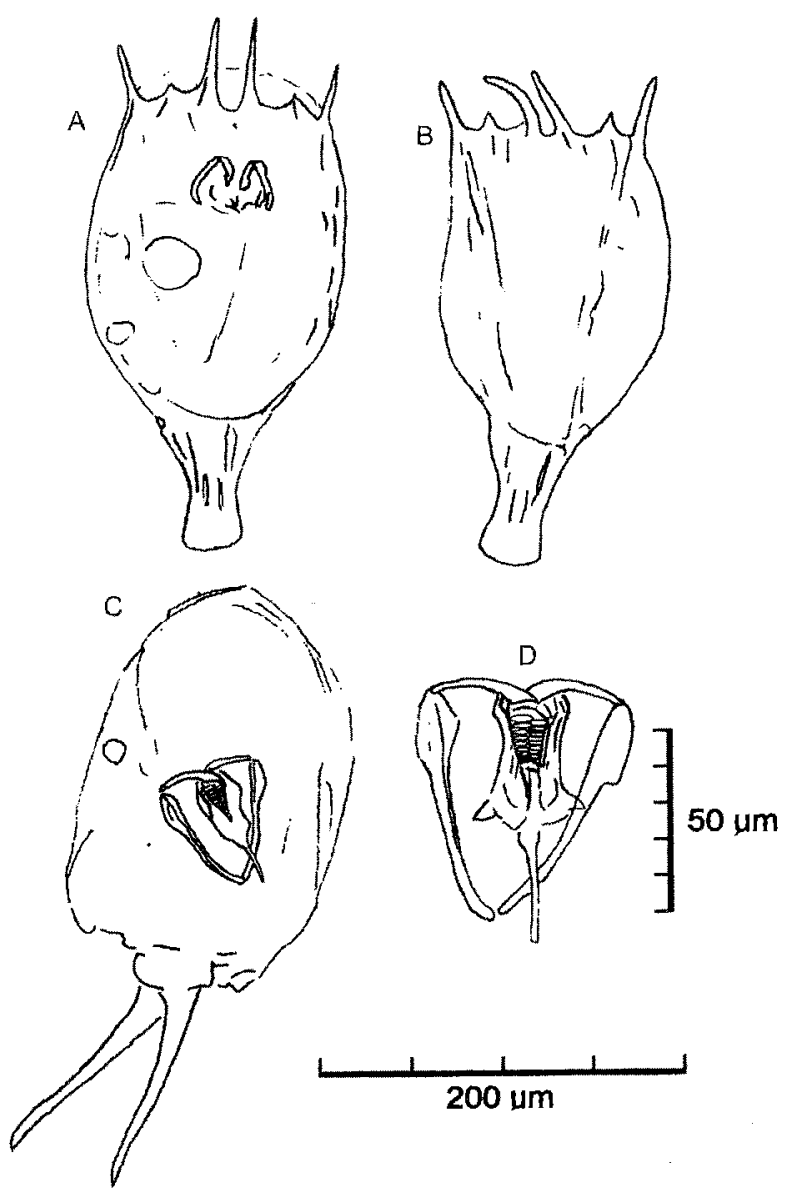

FIG. 2- $(A, B)$ Notholca sp. nov. (A) dorsal view of lorica; (B) ventral view of lorica. ( $C, D)$ Dicranophorus sp. nov.(C) lateral view of whole animal; (D) trophus.

\section{Dicranophorus sp. Fig. 2C, D}

This undescribed species was found in Manning Lagoon. Lightly loricated, with a pair of long toes (fig. 2C) it superficially resembles Cephalodella gibba, a species also present at Heard Island; however, the trophi are completely different. In the genus Dicranophorus the trophus is forcipate (cf. virgate for cephalodellids). The ramiare broadly triangular at the base, curved anteriorly and terminating in two incurved teeth (fig. 2D). The median opening is large and lined with $9+$ pairs of shearing teeth, decreasing in size towards the fulcrum. The alulae are triangular and conspicuous. The fulcrum is long and fractionally shorter than the ramus. The unci are strong and bear a single tooth. The manubria are long, gently curved, the anterior end clubbed and the posterior end smooth with a slight swelling (fig. $2 \mathrm{D}$ ). The body is elongate and transparent. The foot is stout and short and bears two very long and strong toes. At $110 \mu \mathrm{m}$ the toes are approaching one-third of the total length. The trophus, though some $50 \%$ larger at $60 \mu \mathrm{m}$, is similar to that of Dicranophorus mesotis Harring \& Myres, a North American species. As with the undescribed Notholca noted above, more specimens are required before erecting a new species.

In addition to the freshwater invertebrates listed, a number of marine and terrestrial species was found. These interlopers include the torn remains of a marine copepod, which had presumably been dropped by feuding gulls and/or petrels, the ecdysed case of a larval dipteran, which had presumably been blown into Manning Lagoon and all of the springtails (ten species of Colembola are known from Heard Island - Dr S. Chown, pers. comm.). They are found on the water surface and amongst fringing vegetation and have not been included in this survey. They are considered to be terrestrial species.

\section{DISCUSSION}

The freshwater invertebrates found on this visit to Heard Island are listed in table 1. Notwithstanding the arthropods, which are predominately found in the larger bodies of water, the various habitats - lakes, pools, streams and wallows - have very similar faunas. No major seasonal differences could be detected between samples taken in spring (October/ November) and those taken at the end of summer (February), so samples collected at different times from the same location have been combined.

The freshwater worm Allolobophora tenuis was recovered from a variety of habitats - lakes, wallows and streams and this is the 'large enchytraeid' previously reported from Heard Island (Dartnall 1995). All of the arthropods collected on this expedition have previously been found at Heard Island (Dartnall 1995). The two unidentified chydorid species of Dartnall (1995) are now known to be Alona weineki and Pleuroxus wittsteini (Werner Hollwedel, pers. comm.); and the identification of the calanoid copepod Pseudoboeckella remotissima Brehm is corrected to Boeckella brevicaudata. Several species of mite, including the aquatic species Alophagus antarcticus Hughes, were regularly encountered.

This survey failed to find ten species of rotifer reported in an earlier study (Dartnall 1995) — Cephalodella sterae (Gosse), C. ventripes Dixon-Nuttall, Collotheca ornata cornuta (Dobie), Colurella colurus compressa Lucks, Euchlanis sp., Lindia torulosa Dujardin, Notommata glyphura Wulfert, Ptygura sp., Resticula gelida (Harring \& Myres) and Rhinoglena frontalis Ehrenberg; however, an additional six species of rotifer, including two new species, together with three species of nematode were recorded. This disappointingly small increase to the fauna is attributed to unavoidable sampling difficulties and logistic problems. During the spring, when the first collection was made, many of the lakes were still frozen and sampling was only possible either through melt holes, or close to the edge where the ice could be broken. Neither situation is ideal, as both inhibit the action of the plankton net. It was also very early in the season when the flora and fauna had not fully developed after the winter. Analysis of the second collection was delayed because of unavoidable changes to ships' itineraries causing deterioration of the material before examination. The earlier samples (Dartnall 1995) were collected in midsummer using similar equipment and collecting methods but were examined within five days. As a consequence a greater range and number of organisms, particularly the small species, survived until examination.

These records for Heard Island, though few, are sufficient to show remarkable similarities to the freshwater faunas of other subantarctic islands (table 1). No trace of ostracods or aquatic insects was found in the samples and there is increasing evidence to support this as a true record rather than a sampling anomaly. 


\section{ACKNOWLEDGEMENTS}

My thanks to the Australian Antarctic Division for sanctioning this project and for providing logistic support; and to Drs Patricia Selkirk, Mary Skotnicki and Jennie Whinam, who made the first collection, and Dr Dana Bergstrom and Kate Kieffer who made the second. Thanks also to Dr Phil Pugh, Sandra McInnes and Werner Hollwedel who identified mites, tardigrades and anomopodans respectively.

\section{REFERENCES}

DarTNall, H.J.G., 1993: The rotifers of Macquarie Island. ANARE Research Notes 89: 41 pp.

DARTNALL, H.J.G., 1995: The rotifers of Heard Island: preliminary survey, with notes on other freshwater groups. Papers and Proceedings of the Royal Society of Tasmania 129: 7-15.

Dartnall, H.J.G. \& Heywood, R.B., 1980: The freshwater fauna of South Georgia. British Antarctic Survey Bulletin 50: 115-118.

DarTNall, H.J.G. \& Hol.lowday E.D., 1985: Antarctic Rotifers. British Antarctic Survey Scientific Reports 100: 46 pp.

DE SMET, W.H., 2001: Freshwater Rotifera from plankton of the Kerguelen Islands (Subantarctica). Hydrobiologia 446/447: 262-272.

DuCHENE, J.C., 1989: Kerguelen; recherches au bout du monde. Laboratoire Arago 66650 Banyuls sur Mer, France: 360 pp.

Evans, A.J., 1970: Some aspects of the ecology of a calanoid copepod, Pseudoboeckella brevicaudata Brady, 1875, on a subantarctic island. ANARE Scientific Reports 110: $100 \mathrm{pp}$.
FREY, D.G., 1993: Species of Pleuroxus (Anomopoda, Chydoridae) from the subantarctic islands and southernmost South America: a partial unravelling of the Pleuroxus aduncus problem. Hydrobiologia 262: 146-188.

Heywood, R.B., Dartnall, H.J.G. \& Priddle, J., 1979: The freshwater lakes of Signy Island, South Orkney Islands, Antarctica. British Antarctic Survey Data 3: 46 pp.

JANIEC, K., 1993: The Freshwater micro- and meifauna of Admiralty Bay, King George Island, South Shetland Islands. Proceedings NIPR Symposium. Polar Biology 6: 133-138.

KUCZYNSKI, D., 1987: Rotiferos del Genero Branchionus nuevos para la Antartida. Instituto Antarctico Argentino 360: 1-11.

LAIR, N. \& KOSTE, W., 1984: The rotifer fauna and population dynanics of Lake Studer 2 (Kerguelen Archipelago) with description of Filinia terminalis kergueleniensis n. ssp. and a new record of Keratella sancta Russel, [sic] 1944. Hydrobiologia 108: 57-64.

PAGGI, J.C.DE, 1987: Estudios limnológicos en la isla Decepción, Shetland del Sur, Antárdida: aspectos taxonónomicos de los crustaceos del zooplankton. Instituto Antárctico Argentino 339: 1-34.

PAGGi, J.B.G., DE, 1982: Notholca walterkostei sp. nov. y ostros Rotiferos dulceacuicolas de la Peninsula Potter. Isla 25 de Mayo (Shetland del Sur, Antartida). Revista Asociacion de Ciencias Naturales del Litoral 13: 81-95.

RusselL, C.R., 1961: A simple method of permanently mounting Rotifera trophi. Journal of the Quekett Microscopical Club, Series 5, 5: 384-386.

WhinaM, J., 1989: Structure and floristic composition of the Heard Island "pool complex" community. Polar Biology 9: 499-503.

(accepted 24 November 2003) 